\title{
Development and Future Trends of Financial Accounting in Indonesia
}

\author{
Afrizal \\ Faculty of Economics and Business of Jambi University, Jambi 36125, Indonesia
}

\begin{abstract}
This study aims to find out how the development of financial accounting practices in Indonesia, the development of the accounting profession in Indonesia, and how the future trends of financial accounting practices in Indonesia. The results of the study showed that: (1) Thus far, the development of financial accounting practices in Indonesia was quite slow; (2) The development of the professional accounting organizations of Institute of Indonesia Accountants (IAI) and Institute Public Accountants of Indonesia (IAPI) tend to be slow until now, and (3) The tendency of financial accounting practices for the future in Indonesia is to start sequential entry in the notes of financial statement (disclosures) of reporting practices of Corporate Social Responsibility (CSR), reporting practices of human resource accounting, value added accounting, general price level accounting, ABC accounting, inflation accounting, and behavioural accounting.
\end{abstract}

Keywords: Disclosures, CSR, human resources accounting, value added, ABC costing, behavioural accounting. DOI: $10.7176 /$ RJFA/10-16-09

Publication date: August $31^{\text {st }} 2019$

\section{Introduction}

\subsection{Research Background}

Since Indonesia was invaded by the Dutch for three and a half centuries, the development of financial accounting in Indonesia during the days of independence followed developments of financial accounting practiced by the Dutch Government. In 1945, Indonesia became independent, and almost all business patterns and culture inherited what that was left by the Dutch government. At that time, accounting adopted a single-entry book-keeping system. The practice of single-entry accounting continued until the late 1960s. In the early 1970s, the Institute of Accountants of Indonesia (IAI) published a rule book on accounting practices in Indonesia under the title Indonesian Accounting Principles (PAI). Accounting practices in Indonesia regulated by PAI already require accounting with double entry book-keeping patterns. The development of accounting in Indonesia is quite slow. It can be seen from the new PAI books which were renewed in the late 1980s, called the Financial Accounting Standards (SAK).

There are several factors can influencing the development of accounting practices in Indonesia as follows: Accounting managers in companies influence the practices of accounting on how they are directly involved in which they record and prepare financial reports in their companies; Auditors working in Public Accounting Firms (KAP) influence the practices of accounting in Indonesia on how companies conduct accounting practices, then the auditors provide direct recommendations on how accounting practices should be according to their version; Auditors working in the Supreme Audit Board (BPK) influence accounting practices in Indonesia on how stateowned companies and government agencies carry out accounting practices, and then the auditor gives direct recommendations on how accounting practices should be in their opinion; The academics influenced the development of accounting practices through the research they conducted. Research in the field of accounting now has various variations and directions. According to Wolk, Francis, and Tearney (1993) the direction of accounting research can basically be grouped into 5 approaches, namely: (1) Decision-Model Approach, (2) Capital Market Research, (3) Behavioural Research, (4) Agency Theory, and (5) Information Economics.

The Institute of Accountants of Indonesia (IAI) directly influences accounting practices by drawing up the rules they set out in the PAI or SAK which regulates how accounting practices in Indonesia must be implemented. Whereas, the Indonesian Institute of Certified Public Accountants (IAPI) directly influences accounting practices by drawing up rules for the auditors in which they outline in the Public Accountant Inspection Standards (SPAP) which is in it regulating how auditors' practice in auditing accounting practices in private companies in Indonesia.

Initially, the professional accountant organization in Indonesia was only one, namely the Institute of Accountants of Indonesia (IAI). However, as time goes, in 1990, the organization under the IAPI was emerged, namely the Institute of Public Accountants of Indonesia whose members are only accountants who have opened Public Accounting Firms (KAP). in addition, the emerging of IAPI was also because following the professional accountant organization existed in developed countries. Since that time, the professional accountant organization that influenced accounting practices in Indonesia became two organizations.

From the research background above, it can be identified that the main study in this research is how to see the development of accounting practices in Indonesia and how the future trends of accounting practices in Indonesia. 
Since 1970 until now, accounting practices in Indonesia look still very normative. It means that financial reporting still provides information only to what is needed by the company's main stakeholders such as the owners, the creditors, and the government. Meanwhile, information to other parties is still not well accommodated.

\subsection{Research Problem}

Starting from the research background above can be formulated research problems as follows:

1) How does the financial accounting practices in Indonesia develop since 1945 to the present?

2) How does the professional accountant organization in Indonesia develop since 1960 to the present?

3) What are the future trends of development of financial accounting practices in Indonesia?

\subsection{Research Objective}

Starting from the research background above can be formulated research objectives as follows:

1) To find out the development of financial accounting practices in Indonesia since independence to the present.

2) To find out the development of professional accounting organizations IAI and IAPI in Indonesia from 1960 to the present.

3) To find out the future trend of development of financial accounting practices in Indonesia.

\subsection{Research Contribution and Target}

\subsubsection{Research Contribution}

The results of this study are expected to provide two (2) main contributions, namely:

1) Operational. It is expected that information can be useful for owners, directors, and practitioners outside the company in utilizing financial accounting maximally in which it is useful for planning, controlling, and decisions making.

2) Science Development. It is expected to contribute to academics and other financial accounting practitioners in developing and utilizing financial accounting optimally.

\section{LITERATURE REVIEW}

\subsection{Financial Accounting}

Accounting consists of several main processes. First, it is started from the process of collecting transactions evidence relating to transaction and financial events of the company. Then, it is proceeded with the process of identifying and classifying the accounts that will be recorded. Next, the process of recording in accordance with the accounts associated with transaction and financial events of the company. the last, it is continued by preparing financial statements which are the final product of financial accounting to be submitted to the parties that are related to the company (stake holders) or parties related to the organization/institution whose financial statements are prepared. According to Weygandt, Kimmel, and Kieso (2018) stating that financial accounting involves the process of identifying, recording, and communicating economic events.

Financial accounting was discovered in $687 \mathrm{AD}$ which is during the time of Umar bin Khattab became Khalifah $^{\mathbf{1}}$ in the middle east. Treasurer Baitul Mal ${ }^{2}$ of his kingdom has recorded and used the main basic equation:

\section{Assets $=$ Debt + Capital}

It means that every type of financial transaction or financial event of a company/organization/ government institution must involve 2 two elements of the main equation above. Therefore, if a concise financial accounting report is prepared, it will only contain the three elements in the equation above. In fact, if it is described in detail of the existed three elements in the equation, it will show sub-elements which are numerous and even different for each type of company, organization, and government institution. The final result of the financial accounting process is a report called a Financial Statement. There are 2 main components of financial statements, namely: the balance sheet and the profit and loss statement.

The balance sheet consists of 3 main sub elements, namely; Assets, debt, and capital/equity. Assets consist of the following elements: cash, accounts receivable, office supplies, inventory, prepaid insurance and prepaid rent, land, buildings, equipment, home furniture and appliances. Meanwhile, debt consists of account payable, shortterm bank debt, and long-term bank debt, and other debts. Capital/equity consists of owner's paid-in capital and retained earnings or not-shared earnings.

Calculation or statement of profit and loss consists of 4 main elements, namely: volume of sales or revenue, cost of goods sold, costs, and earning. Volume of ales represents gross income as a result of selling merchandise or goods produced from an industrial company, while the results of service sales are called revenue. Cost of goods sold is the purchase price of goods to be sold or the cost of production of goods to be sold to industrial companies producing their own goods. Costs are all operational costs incurred consisting of marketing costs and

\footnotetext{
${ }^{1}$ a title given to the successor of the Prophet Muhammad in Muslims leadership

2 "House of Wealth." it was a financial institution responsible for the administration of taxes in Islamic states
} 
administrative costs in the office including salaries of office employees.

\subsection{Decision Making}

Making a choice between two or more alternatives is a decision. before a decision is taken by an individual or by a manager in the company, of course, there is a process, and the process is a decision-making process. A decisionmaking model describing how individuals should behave in order to maximize an outcome is called by the "optimizing model". An optimization model of decision making involves 6 steps that should be known by an individual, either explicitly or implicitly when making decisions, namely: confirm the need for a decision, identify decision criteria, allocate grade to those criteria, develop alternatives, evaluate alternatives, and choose the best alternative (Robbins, 2016). The satisficing model is a decision-making model where decision makers choose solutions that are considered "good enough", namely satisfactory and sufficient. According to this model, managers or individuals make decisions by making simple models can reducing the complexity of the problem. The implicit favourite model is a moderate decision-making process where in the decision process, the decision maker implicitly chooses an alternative which is preferred subjectively. In other words, decision makers are irrational and not objective. The intuitive model is a process of decision-making through an unconscious process created from within a filtered experience, or it can also be said to be the result of the power of the sixth sense of decision maker. However, intuition is not free from rational analysis, instead the two are complement each other.

According to an academic view, variables that can influence the development of accounting practices in Indonesia are accounting managers of company, auditors of Public Accounting Firms (KAP), auditors of Supreme Audit Institution (BPK), Institute of Accountants of Indonesia (IAI), the Institute of Public Accountants of Indonesia (IAPI), and accounting researcher.
Influencing Factors:
1. Accounting Manager of Company
2. Auditors of KAP
3. Auditors of BPK
4. IAI
5. IAPI
6. Accounting Researcher

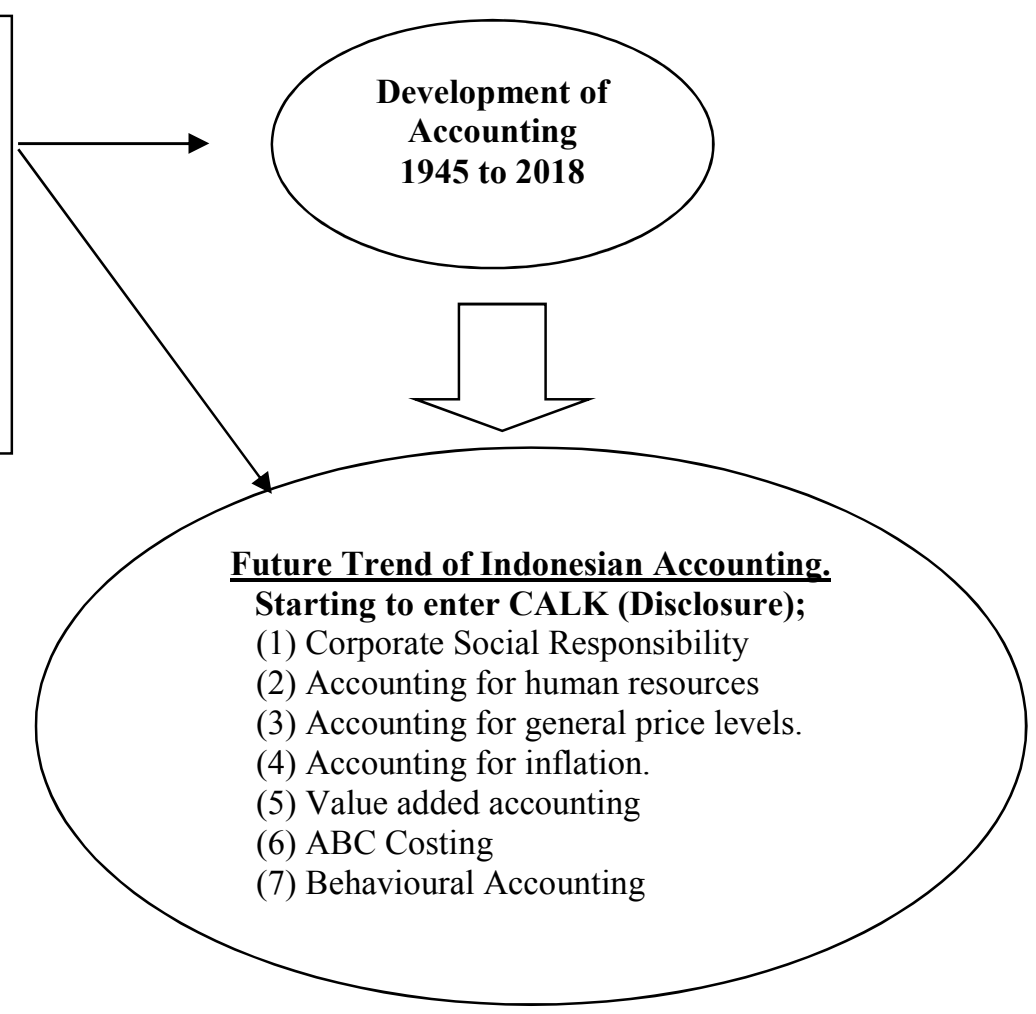

Figure 1. Research framework

\subsection{Hypothesis}

Starting from the problem, the research framework can be deduced the following hypothesis:

1) The development of financial accounting practices in Indonesia since 1945 to present is quite rapid

2) The development of professional accountant organizations (IAI and IAPI) in Indonesia since 1960 to present tends to be slow.

3) The direction of the development of management accounting practices for the future in Indonesia is the starting point of CSR (Corporate social responsibility) accounting practices, human resource accounting, general price level accounting, inflation accounting, value added accounting, ABC Costing, and behavioural accounting which are all included in the notes to financial statements or disclosure. 


\section{RESEARCH METHOD}

\subsection{Research Object}

The objects of this study are accounting practitioners in large companies, supervisors or external practitioners, namely auditors of Public Accountant Firm (KAP), auditors of Supreme Audit Institution (BPK), administrators of accountant professional organizations of Institute of Indonesia Chartered Accountants (IAI), administrators of accountant professional organizations of Indonesian Institute of Certified Public Accountants (IAPI), and research academics.

\subsection{Research Method}

The research method used in this study is the survey method, which is collecting data (information) using questionnaires and telephone interviews to accounting practitioners (accounting managers) of large companies and supervisors or executing external practitioners, namely auditors of Public Accountant Firm (KAP), auditors of Supreme Audit Institution (BPK), administrators of accountant professional organizations of Institute of Accountants of Indonesia (IAI), administrators of accountant professional organizations of Institute of Public Accountants of Indonesia (IAPI), and accounting researcher.

\subsection{Population and Sample}

The population of this study was accounting managers in large companies, auditors of KAP, auditors of BPK, central and regional administrators of IAI, central and regional administrators of IAPI, and research academics. The sample method used is purposive sampling method which is by determining the sample evenly against respondents who are relevant to the object of research. The number of samples and respondents are as follows:

1) 100 of managers in large companies,

2) 100 of auditors of KAP,

3) 100 of auditors of BPK,

4) 100 of central and regional administrators of IAI,

5) 100 of central and regional administrators of IAPI, and

6) 100 of accounting researcher

\subsection{Data Collection Techniques}

Data collection techniques for each variable are carried out using a list of questions (questionnaire) with the following details:

a. Data through a list of questions to the relevant respondents as a sample of observations.

b. Interviewing relevant respondents through telephone directly as sample of observations.

c. Taking data from the literature relating to the history of financial accounting in Indonesia.

\subsection{Data Analysis Method}

In this study, a descriptive analysis method was used. It is done by making a direct tabulation on the data of the variables to be analysed, then comparing the percentage of the values and the average of the value. The results of most respondents' answers became the first rank, the answers of the second most respondents became second rank, and so on.

\section{IV.RESULTS AND DISCUSSION}

\subsection{Result}

From the results of the survey through questionnaires and interviews via telephone can be presented the results of the study in the form of tables 4.1., table 4.2., and table 4.3. as below:

Table.4.1. Data on Development of Financial Accounting since 1945 to 2018.

\begin{tabular}{|c|l|c|c|c|c|}
\hline \multirow{2}{*}{ No. } & \multirow{2}{*}{ Object / Respondent } & \multicolumn{4}{|c|}{ Development of Accounting Practices } \\
\cline { 3 - 6 } & & Rapid & Moderate & Slow & Total \\
\hline 1 & Company Manager & 11 & 26 & 63 & 100 \\
\hline 2 & Auditors of KAP & 11 & 52 & 37 & 100 \\
\hline 3 & Auditors of BPK & 12 & 19 & 69 & 100 \\
\hline 4 & Administrators of IICA & 42 & 35 & 23 & 100 \\
\hline 5 & Administrators of IICA & 39 & 30 & 31 & 100 \\
\hline 6 & Research Academics & 10 & 18 & 72 & 100 \\
\hline & Total & 125 & 180 & 295 & 600 \\
\hline
\end{tabular}

The results of table.4.1 above showed that the development of financial accounting practices in Indonesia was slow showing 295 respondents, was moderate showing 180 respondents, and was fast showing 125 respondents. Thus, it can be concluded that the development of financial accounting practices in Indonesia from 
1945 to 2018 was slow.

Table.4.2. Data on the development of Professional Accounting Organization (IICA and IICA) from 1960 to 2018.

\begin{tabular}{|c|l|c|c|c|c|}
\hline \multirow{2}{*}{ No. } & \multirow{2}{*}{ Object / Respondent } & \multicolumn{3}{|c|}{ Development of Accounting Practices } \\
\cline { 3 - 6 } & & Rapid & Moderate & Slow & Total \\
\hline 1 & Company Manager & 4 & 33 & 63 & 100 \\
\hline 2 & Auditors of KAP & 22 & 52 & 26 & 100 \\
\hline 3 & Auditors of BPK & 15 & 27 & 58 & 100 \\
\hline 4 & Research Academics & 10 & 29 & 61 & 100 \\
\hline \multicolumn{2}{r|}{ Total } & 51 & 141 & 208 & 400 \\
\hline
\end{tabular}

The results of table.4.2 above showed that the development of the professional accountant organization consisting of IAI and IAPI in Indonesia was slow showing 208 respondents, was moderate showing 141 respondents, and was fast showing 51 respondents. Thus, it can be concluded that the development of professional accountant organizations consisting of IAI and IAPI in Indonesia from 1960 to 2018 was slow.

Table.4.3. Data on The Developments of Future Accounting

\begin{tabular}{|c|l|c|c|c|c|c|c|c|}
\hline \multirow{2}{*}{ No. } & \multirow{2}{*}{ Future Trend Accounting } & \multicolumn{6}{|c|}{ Object / Respondent } & \multirow{2}{*}{ TOTAL } \\
\cline { 3 - 8 } & & Psh. & KAP & BPK & IICA & IICPA & AA & \\
\hline 1 & Corporate social responsibility & 36 & 46 & 31 & 47 & 37 & 56 & 253 \\
\hline 2 & Human resources accounting & 22 & 20 & 27 & 28 & 22 & 18 & 137 \\
\hline 3 & General price level accounting & 8 & 6 & 11 & 8 & 9 & 8 & 50 \\
\hline 4 & Inflation accounting & 11 & 4 & 5 & 3 & 9 & 0 & 32 \\
\hline 5 & Value added accounting & 14 & 9 & 7 & 11 & 16 & 10 & 67 \\
\hline 6 & ABC Costing & 7 & 11 & 12 & 3 & 7 & 8 & 48 \\
\hline 7 & Behavioural accounting & 2 & 4 & 7 & 0 & 0 & 0 & 13 \\
\hline & TOTAL & 100 & 100 & 100 & 100 & 100 & 100 & 600 \\
\hline
\end{tabular}

The results of table.4.3 above showed that the trend of future accounting developments in Indonesia for accounting social responsibility of CSR (Corporate social responsibility) ranks first showing 253 respondents; the second rank is human resources accounting showing 137 respondents; the third rank is value added accounting showing 67 respondents; the fourth rank is general price level accounting showing 50 respondents; the fifth rank is $\mathrm{ABC}$ costing accounting showing 48 respondents; the sixth rank is inflation accounting showing 32 respondents; and the seventh rank is behavioral accounting showing 13 respondents. Thus, the future trends of financial accounting practices in Indonesia will be completed sequentially included in the notes to the financial statements (disclosures), starting from accounting social responsibility of CSR (corporate social responsibility), human resource accounting, value added accounting, general price level accounting, ABC costing accounting, inflation accounting, and behavioural accounting.

\section{CONCLUSIONS AND SUGGESTIONS}

\subsection{Conclusions}

Starting from the problem, the research framework can be deduced the following hypothesis:

1) The development of financial accounting practices in Indonesia since 1945 to present is quite rapid

2) The development of professional accountant organizations (IAI and IAPI) in Indonesia since 1960 to present tends to be slow.

3) The direction of the development of management accounting practices for the future in Indonesia is the starting point of CSR (Corporate social responsibility) accounting practices, human resource accounting, general price level accounting, inflation accounting, value added accounting, ABC Costing, and behavioural accounting

\subsection{Suggestions}

1) Factors influencing the development of accounting practices in Indonesia are practitioners in large companies that have gone public, professional organizations of IAI and IAPI, auditors of KAP, auditors of BPK, and research academics in accounting field.

2) To accelerate the progress of the future development of accounting practices in Indonesia, there must be a joint forum between accounting practicioners residing in large companies, organizations of practitioners in large companies that have gone public, administrators of professional organizations of IAI and IAPI, auditors of KAP, auditors of BPK, and research academics in the accounting field.

\section{References}

Afrizal., “Accounting Theory”., Published by Salim Media Indonesia. Jambi. Fisrt Edition 2018. 
Ashar, Kalpesh., "Financial Accounting: Essentials You Always Wanted to Know"., Vibrant Publisher. $4^{\text {th }}$ Edition”. 2019.

Atkinson, Anthony A., Rajiv D. Banker., Robert S. Kaplan., and S. Mark Young., "Management Accounting"., Second Edition, New Jersey; Prentice-Hall International, Inc. 2018.

Blokdyk, Gerardus., Hedge Accounting A Complete Guide”. Emereo Pty.Ltd. Publisher International Edition 2019.

Bloom, Robert and Pieter T. Elgers., "Accounting Theory and Policy: A Reader" Second Edition, San Diego; Harcourt Brace-Jovanovich, Publishers, 1987.

Diamond, Michael A.,"Financial Accounting",, Third Edition, Cincinnati; College Division. South-Western Publishing Co, 1993.

Gleim, Irvin M., "Financial Accounting and Reporting”, CPA Review. Paper back.With Connect 2019.

Godwin et.all “Determinant of Audit Quality of Quoted Industrial Goods Sector in Nigeria”., Research Journal of Finance and Accounting. 2018.

Horngren, Charles. T and Walter T. Harrison.JR., “Accounting”., New York; Prentice-Hall International Editions, 1989.

Law Library.," Public Governance, Performance and Accountability”., Australia Edition. 2018.

IAI., "Standar Akuntansi Keuangan". Edisi Ikatan Akuntan Indonesia, 2018

Kam, Vernon.m., “Accounting Theory”., Second Edition. New York; John Wiley \& Sons, 2017.

Kaplan, Robert S and Anthony A.Atkinson., “Advanced Management Accounting”., Second Edition. New Jersey; Prentice-Hall International Editions, 2017.

OECD., National Accounts of OECD Countries, Financial Account”.. OECD Publisher. 2018.

Robbins, Stephen P., "Organizational Behavior: Concepts, Controversies, and Applications., Seventh Edition. San Diego; Prentice-Hall International, Inc. 2016.

Ryan, Bob., Robert W. Scapens, and Michael Theobald., "Research Method and Methodology in Finance and Accounting", San Diego; United States Edition Published by Academic Press Inc. 1992.

Schroeder, Richard.G., Myrtle Clark, and Levis D. Mc.Cullers., "Accounting Theory: Text and Readings". Fourth Edition, New York: John Wiley and Sons. 1991.

Smith, Jay. M and K. Fred Skousen., "Intermediate Accounting”., Eleventh Edition, Cincinnati; College Division. South-Western Publishing Co, 1992.

Stickney, Clyde P., Roman L. Weil., and Sidney Davidson., "Financial Accounting: An Introduction to Concepts, Methods, and Uses"., Sixth Edition, Florida; Harcourt Brace Jovanovich College Publishers, 1991.

Walther, Larry M., "Financial Accounting"., Amazon Publisher, 17 ${ }^{\text {th }}$ International Edition. 2018.

Walther, Larry M., "Managerial Accounting"., Amazon Publisher, 17 $7^{\text {th }}$ International Edition. 2019.

Watts, Ross L and Jerold L. Zimmerman., "Positive Accounting Theory"., New Jersey: Prentice-Hall International Inc. 1986.

Wild John J, “Managerial Accounting”., Paper back. With Connect 2018. $6^{\text {th }}$ Edition. 2018.

Wolk, Harry.I., Jere.R. Francis, and Michael G. Tearney., "Accounting Theory: A Conceptual and Institutional Approcah", 5th Edition, Boston: PWS-KENT Publishing Company. 2015.

Urip, Sri (2018).," CSR Strategies, Corporat Social Responsibility: For a Competitive Edge in Emerging Markets"., A John Wiley \& Sons (Asia), Ltd, Publication. Singapore 2018

Visser, Matten, Pohl, and Tolhurst (2018).," The A to Z Corporat Social Responsibility"., A John Wiley \& Sons, Ltd, Publication. Revised Edition 2018.

Weygandt, Kimmel, and Kieso., “Accounting Principles”., John Wiley \& Sons, Ltd, Publication. Eleventh Edition. Internasional Student Version. 2014

Weygandt, Kimmel, and Kieso., "Financial Accounting"., John Wiley \& Sons, Ltd, Publication. IFRS Edition 2018.

Whittingtin and Bain., "Financial Accounting and Reporting”, Wiley CPA Aexel Exam Review 2018.

Author: Afrizal (D'04-D'08--CH '15--'19). Dean of Economics Faculty of Jambi University (2004-2008), Dean of Economics Faculty of Jambi University (2008-2012), Chairman of Indonesia Accountants Institute for Jambi Province (2015-2019). Birth: 27 July 1959 Bukittinggi, Indonesia. Education: Bachelor in Accounting at Andalas University, Padang, Indonesia. Master in Accounting 1996 at Padjadjaran University, Bandung, Indonesia. Doctor in Accounting 1999 at Padjadjaran University, Bandung, Indonesia. 